\title{
Forced up or down? \\ The impact of forced migration on social status
}

\author{
Isabel Ruiz \\ Harris Manchester College \\ University of Oxford \\ Melissa Siegel \\ Maastricht Graduate School of Governance \\ UNU-Merit \\ University of Maastricht \\ Carlos Vargas-Silva \\ COMPAS \\ University of Oxford \\ Contact: \\ Carlos Vargas-Silva \\ COMPAS \\ 58 Banbury Road \\ Oxford \\ OX2 6QS \\ UK \\ carlos.vargas-silva@compas.ox.ac.uk \\ +4401865284975
}




\title{
Forced up or down? \\ The impact of forced migration on social status
}

\begin{abstract}
Using a dataset on Burundian refugee returnees, this paper explores returnees' perceptions of the overall impact of migration on their community and household level social status. Particular attention is placed on the role of gender and duration of migration. After controlling for relevant factors, gender does not seem to affect the perceived impact of migration on alienation from the community or the relative position of the returnee in the household. On the other hand, women are less likely than men to perceive that migration has improved their social status, increase their ability to contribute to the community, or given them more decision making power. Results suggest that those returnees who spent longer periods of time abroad have a greater tendency to perceive migration as having a positive impact on their social status. The paper discusses the policy implications of the results for return migration in a post-conflict context.
\end{abstract}

Keywords: Forced Migration, Return Migration, Refugee, Gender, Conflict, Burundi 


\section{INTRODUCTION}

The perceptions of forced migrants regarding the consequences of their migration experience are likely to vary according to the different stages of the migration process (e.g. displacement, resettlement, repatriation, etc.). Of particular importance are the perceptions of those forced migrants who return home. These perceptions are important in post-conflict settings because of their influence on household cohesion, community reconciliation and the peace process. If forced migration has important impacts on the social structure of communities and households then it may also affect future levels of social capital and the willingness of individuals to enter into household or community level collaborative efforts. Some of these collaborative efforts, such as joint insurance schemes or joint-liability loans, could have important repercussions for economic security at the community level.

There is a large literature exploring the perceptions of refugees concerning the consequences of the displacement process, mainly regarding post-traumatic stress disorder and other mental health issues (e.g. Ai et al., 2002; Cardozo et al., 2004; Davis, 2000; Hinton et al., 2009; Pavlish, 2007; Sideris, 2003). The majority of the analysis is qualitatively in nature and quantitative analysis remains relatively scarce. Previous quantitative analysis has focused on the impact of displacement on labour markets, production, prices, and health outcomes (e.g. Alix-Garcia and Saah, 2009; Alix-Garcia et al., 2012; Baez, 2011; Kondylis, 2010). The main reason for the scarcity of quantitative studies is the lack of adequate quantitative data on refugees' perceptions.

This paper uses recently collected quantitative data from returning migrants (returnees from now on) in a post-violence context to explore the post-return perceptions of their migration process. The focus is on the perceived impact of the overall migration process (including displacement and return migration) on community and household level social 
status. The analysis places special emphasis on how gender and length of migration affect returnees' perceptions.

In general, the roles of men and women in society are conditioned by cultural and social expectations. As such, men and women are likely to have different perceptions regarding their roles in the community and the household. Forced migration brings additional complexity to the issue because conflict and displacement affect men and women differently (El-Bushra, 2000; Gurujara, 2000; Bermúdez Torres, 2002). Daley (2008) explains that in many situations of violence, including Burundi, the likelihood of getting killed, conscripted, tortured or raped varies significantly across genders. Yet, even factors that affect the household as a whole such as the loss of land, and crops, or the death of family members can affect men and women differently because of different degrees of 'sensitivity' to these events.

Another factor that is explored in the paper is the impact of duration of stay abroad. In the data used for this analysis a returnee is defined as anyone who has lived at least three months in another country. This definition involves very different displacement experiences as some forced migrants have to wait for a decade or more before returning home. It is very likely that the length of time spent abroad has important implications for the impact of forced migration on social standing. Time spent abroad could impact social standing via two channels: the 'migrant behaviour' and the 'community reception' channels. In the 'voluntary migration' literature there is extensive evidence that planned and actual length of stay abroad have important implications for 'migrant behaviour', including savings, investments, remitting patterns, types of jobs, integration levels, and human capital acquisition, among others (e.g. Dustmann and Mestres, 2010; Merkle and Zimmerman, 1992). These factors could have a major impact on the post-return realities and perceptions of returnees. On the other hand, returnees who have spent longer periods of time abroad could be perceived as 
outsiders by the community or household members who stayed behind, a factor which may affect their own perceptions of social standing.

This paper uses data collected in Burundi during 2011. Burundi is a small and densely populated country in the African Great Lakes Region which has experienced repeated waves of civil conflict. After the signing of the Arusha Peace and Reconciliation Accords in 2000 and the instalment of the first democratically elected government in 2005 , the country has been on a path towards stability and peace. Over the past decade, more than 500,000 refugees returned from exile. Many of these refugees had been in exile for over thirty years while others had left in the early 1990s. In the context of this large wave of refugee return it is now important to explore how the overall process of displacement (i.e. original migration, life in exile and return) affected returnees and the gender differences in those impacts.

\section{BACKGROUND: CONFLICT HISTORY, EXILE AND THE PROCESS OF RETURN}

\section{Civil conflict in Burundi}

Burundi has experienced frequent civil conflict since it gained independence from Belgium in 1962. Ethnicity has played a major role and these conflicts have involved confrontation between the country's two main ethnic groups: Hutus and Tutsis. After independence, the country underwent an escalated conflict that resulted in the 1972 genocide. It has been reported that about 3.5 percent of the population was killed within a few weeks (Lemarchand and Martin, 1974; Lemarchand, 2008). Between 1972 and 1973, an estimated 150,000 to 200,000 Burundians fled the country and relocated in the neighbouring countries of Tanzania, Rwanda and the Democratic Republic of the Congo (Daley, 2008). The mass exodus during the 1972 crisis was followed by smaller outflows of refugees in 1988 and 1991. 
The latest large-scale conflict erupted in 1993. On October of that year Burundi's first democratically elected Hutu President, Melchior Ndadaye, was assassinated by Tutsi soldiers after just four months in office. As a result of the assassination, violence broke out between the two ethnic groups, and an estimated 100,000 people died within a few months (United Nations, 1996). Overall, the conflict lasted over a decade and claimed the lives of over 300,000 individuals (Martin, 2003; Martin and Hiddleston, 2006). It has been reported that during this crisis, somewhere around 400,000 to 700,000 individuals fled the country with an important share of the population also fleeing to Tanzania, Rwanda, and the Democratic Republic of the Congo (Ngaruko and Nkurinziza, 2005, Fransen and Siegel, 2011, Fransen and Kushminder, 2012).

\section{Refugees and Repatriation of Refugees}

Burundians have historically been one of the largest protracted refugee populations in Africa. It is estimated that displacement in Burundi affected 1.2 million people (Ngaruko and Nkurinziza, 2005). However, since the end of conflict and the return of democracy to the country there has been a large surge of refugee return (UNHCR, 2011; UNHCR, 2012).

Conditions for the 1972 refugees that were living in exile greatly differed from those from the 1993 crisis. These two main refugee cohorts are referred to as the 1972 (or "old") caseload refugees and the 1993 caseload. While there were a variety of destination countries, in both instances a great share of the refugee population relocated to the neighbouring country of Tanzania. Many refugees sought refuge in settlement camps while many others self-settled. The "old caseload" sought refuge in designated villages and were relocated to settlement camps in relatively inhabited areas (officially known as the "old settlements") in the North East region of Tanzania (Tabora, Rukwa, and Shinyanga) (Amnesty International, 2005). Those living in settlements had access to some land and were able to grow crops that 
allowed them to be self-sufficient. They also had the possibility of assimilation to the new culture through social acceptance and access to education (Robinson and Riiskjaer, 2010). On the other hand, the 1993 cohort was placed in refugee camps in the Kagera and Kigoma regions where the conditions were much different. Early arrivals had access to land for crops while later arrivals faced scarcity and more constrained situations (Amnesty International, 2005, Robinson and Riiskjaer, 2010).

The return and repatriation of Burundian refugees has been a conflicted process. There have been informal return processes along with several attempts by international organizations and the governments of Burundi and receiving countries. In particular, the signing of the Arusha Peace and Reconciliation Agreement in the year 2000 was key in the repatriation process for Burundians. At the prospect of the signing of a repatriation agreement, in 2000 many Burundians started to return voluntarily from exile. With the participation of the Tanzanian government, a UNHCR repatriation program officially started in 2002. As shown in Figure 1, since 2000 there has been a large wave of returnees with most returnees came from Tanzania (see Figure 1).

\section{[Figure 1]}

Not only different refugee experience can impact the perceptions of return but also the conditions upon which the returnee faces on arrival back to the country of origin. There are different accounts on the repatriation process. Some of the returnees had voluntarily returned; others were part of repatriation agreements between the UNCHR and the governments of Burundi and Tanzania. Others, as it is the case of the 1972 caseload, were instead offered naturalization. In 2008, for example, the Tanzanian government granted citizenship to 162,000 refugees and helped resettled more than 12,000 Burundian refugees to third countries since 2005 (UNHCR, 2012). 
According to UNHCR data, there are still about 35,200 refugees still living in Tanzania, many of whom are young (about 59\% are younger than 18) and are under considerable pressure to go back to Burundi. The last refugee camp in Tanzania, the Mtabila camp, effectively closed in December of 2012. Donations and assistance to remaining refugees has decimated and is, in many cases non-existent, due to pressures for repatriation. In most cases, remaining refugees have lost their "refugee status" (UNCHR, 2012).

Access to land has been one of the major obstacles in the reintegration process of returnees. Upon return, many returnees found themselves either landless or with their land occupied by others (UNHCR 2009, 2010, Fransen and Kushminder, 2012). During 2012, more than 3,200 former refugees had registered as landless (UNHCR 2012). Another challenge faced in the process of reintegration is related to the age of those that have returned. Many of the returnees were below 18 years old and were born in camps (second generation refugees). Many of these, children of former refugees born in exile, had never even set foot in Burundi. Many of them do not speak the native language and the few that had access to education, faced a curriculum in a different language (French instead of English).

Using a national representative sample, our study explores evidence in terms of the perception of returnees regarding their status in the community. Our sample allows us to draw general conclusions by controlling for a large set of covariates. We place special attention to the duration of exile and the role of gender. Refugees that have spent a longer time in exile may face very different challenges than the rest of returnees (as it the case of 1972 caseload). Also, while the background experience greatly differs from individual to individual, gender adds to the perceptions and feelings of returnees. Although there is a scarcity of reliable official statistics there is plenty of anecdotic evidence from NGOs and international organisations which suggest that many women in Burundi suffered from sexual abuse during the conflict. The motivations for rape in Burundi were multiple and varied from 
military strategies to reprisal, but often included straightforward sexual assault with no ulterior motive (Daley, 2008). Some reports also suggest that sexual violence continued even after peace was declared (e.g. Niyonizigiye and le Roux, 2011).

\section{PERCEPTIONS AND GENDER DIFFERENCES: THEORETICAL INSIGHTS, AND EXISTING EVIDENCE}

\section{Perceptions and gender}

Gender is a critical source of intra-household tensions that can affect resource allocations in the context of international migration and there is an extensive literature looking at this topic (e.g. Pfeiffer et al. 2007). A classic example is that women left at home while their husbands migrate abroad, often experience changes in their role in the household and have to assume greater responsibilities (de Haas and Van Rooij, 2010). Some studies suggest that female autonomy may persist even after their husbands return (Yabiku et al., 2010). Even when the whole household migrates there could still be changes in the internal dynamics of the household due to changing roles of men and women (Boyd and Grieco, 2003). In the context of forced migration, women's roles are often re-defined by becoming the protectors of family, the providers and by taking on more responsibilities while men have been reported to find themselves uprooted and unable to re-establish their position as respected decision makers (Gurujara, 2000).

The potential differences between women and men do not necessarily imply that they will perceive the displacement and return process completely differently. For instance, Table 1 reports the responses in the survey used in this paper to the statement: Overall, I feel that migration has been a mistake. The possible responses to the question range from -2 to +2 , with -2 indicating strong disagreement with the statement, 0 being neutral and +2 indicating 
strong agreement with the statement. In both cases (women and men), the average response is negative and significantly different from zero. Given that violence was the main driver of emigration, it is not surprising that both, males and females, strongly disagree with the statement. However, the perception that original migration was not a mistake is much stronger among men relative to women. In fact, the difference between the average response of women and men is positive and significantly different from zero. This indicates that even if the general feeling is negative for individuals of both genders, the degree of 'sensitivity' to different aspects of the displacement process can vary significantly by gender.

[Table 1]

Results such as the one presented above, could have multiple roots. For instance, it could be that men are simply inclined to be more drastic in their responses (i.e. selecting extreme responses) than women. As it will be shown below, this is not the case and in many instances women are the ones providing the more extreme responses.

Even if there is not a distinctive tendency to provide extreme responses across gender lines, it is likely that the same set of circumstances and experiences are perceived differently by men and women. There is extant evidence in the psychology literature which suggests that women experience emotions more strongly than men (e.g. Harshman and Paivio, 1987). Women tend to have particularly higher levels of anxiety and distress regarding the possibility of undesirable outcomes (Ritsner et al. 2001). This research also shows that in equal circumstances, women often feel fear, while men feel anger (Grossman and Wood, 1993). The economics literature has also provided ample evidence that there are gender differences in factors such as risk taking and attitude towards competition. Most studies suggest that women are more risk averse than men and more averse to competition than men (Andersen et al., 2013; Croson and Gneezy, 2009). 
It is challenging to provide definite evidence for these various possibilities in the forced migration context because often women and men have different experiences during the displacement process (Martin, 2004). Variations in their responses to the questions could result from actual differences in experiences, rather than different perceptions of the same events. The estimations presented in this paper control for many differences in the conflict and displacement experiences of the returnees. Yet, even with these controls in place it is not possible to conclude that differences in responses across gender lines result exclusively from gender differences in their perception of the migration process rather than actual different experiences.

\section{DATA AND METHODOLOGY}

\section{Data collection and sample}

The fieldwork for this study took place between January and March 2011 in all 17 provinces of Burundi. The main dataset has information on 1,500 households in Burundi. Of the 1,500 households (i.e. 15 households in each of the 100 collines), 286 households reported having at least one returnee in the household (37\% female and $63 \%$ male). In addition to this dataset, we use information collected about the 100 communities in which the survey was conducted.

An in-depth interview was conducted with the returnees of those households. If there was more than one returnee per household, then one of the returnees was randomly selected for the interview. The data from the in-depth interviews with returnees, which include questions about the perceived impact of migration, is used for the statistical analysis in this paper, along with controls for community level characteristics. Once we clean the data there is complete information for between 225 and 246 returnees for the different estimations. While this is not a particularly large sample, it is very unique given the scarcity of quantitative data on perceptions of returnees in a post-conflict context.

\section{Methodology}


The analysis is split into two parts. These parts are the perceived impact of the overall migration process (including displacement and return) on: 1) standing within the community in Burundi, and 2) standing within the household. The paper places special emphasis in differences in these perceived impacts across gender lines and in relation to length of stay abroad.

Part A of Table 2 presents the questions which are analysed for the first area of interest, the perceived impact of migration on community social status. There is an extensive sociology literature on the definition and measurement of "social status", which is primordially based on the idea that a differentiated and unequal structure exists in a given society (e.g. Hollinsghead, 1975). One of the many insights from this literature is that social status is a multidimensional concept. Therefore, we use three different questions to explore the impact of forced migration on community social status. The first question directly asks about improvements in social status in Burundi as a result of the migration process. However, the returnee could strongly disagree with the question, and this will not indicate that the returnee perceives a decrease in his or her social status. Questions 2 and 3 explore in more detail the relationship of the returnee with the community concerning the impact of migration on the possibility of contributing to the community and feelings of alienation from the community. These questions provide additional insights on the impacts of the migration process on community related aspects.

On average both, men and women, reject the idea that migration has improved their social status in Burundi or increased their ability to contribute to the community. Respondents from both genders also expressed that migration has alienated them from the community. There are significant differences between the two groups concerning the impact of migration on social status in Burundi and the ability to contribute to the community. In 
both cases, women are more negative concerning the impact of migration. The difference between genders is not significant for feelings of community alienation.

[Table 2]

Part B of Table 2 presents the questions which are analysed for the second area of emphasis. We look at responses to different questions to gain a comprehensive understanding of the impact of migration on standing within the household. On average, women believe that the overall migration process has decreased their status within the household, while the contrary holds true for men. The mean response for both women and men is significantly different from zero, as it is also the difference between the means across genders. Both men and women tend to disagree with the statement that migration gave them more decision making power within the household. Yet, the feeling seems to be much stronger among women.

In the next section we explore these questions further by estimating regressions which include a series of individual, household, and community level control variables. The community specific variables come from a community leaders' survey that was conducted in parallel to the household level survey. Each colline in Burundi is run by an elected chef de colline (i.e. village chief). In most cases respondents to the community leaders' survey were the chef de collines. The variable Land available indicates the availability of land in the community (higher values indicate more availability). The variable Employment available indicates the availability of employment in the community (higher values indicate more availability). Ethnic harmony indicates that there are good relationships between different ethnic groups in the community (higher values indicate a better relationship among different ethnic groups).

In the data, a return migrant is defined as an individual who has returned to Burundi either voluntary or forced to live fulltime after a minimum of three consecutive months living 
in another country. This definition includes individuals that migrated to a neighbouring country for a few months and individuals who stayed abroad for many years. In order to control for the broad nature of this definition we include a series of migration related control variables. These variables are also important to control for the impact that different migration experiences have on post-return perceptions. The variable time since return indicates the number of years since the person returned to Burundi ( 0 if the person returned in 2011). The variable length of migration indicates the number of months that the person lived abroad. Finally, the variable part of host society indicates the degree to which the person did feel part of the society in the destination country. Higher values for this variable indicate that the person felt a stronger attachment to the host society.

In addition to the community level controls and the migration variables, the regressions control for the following returnee characteristics: gender (female $=1$, otherwise 0), age (years), marital status (married $=1$, otherwise 0), education (years) and employment status (employed $=1$, otherwise 0 ). The responses to the income questions did not seem to truly represent the actual wealth of the households, as many of the households depend on agriculture and informal activities for subsistence. Therefore, the estimations include a series of variables which are proxies for household level wealth. These are: a subjective wealth scale (larger values indicate greater wealth relative to other households in the community), a variable indicating that the household owns land, and a variable indicating that the household owns animals (limited to poultry, goats, sheep, pigs, cows, and oxen). Appendix A provides the definitions of all variables included in the estimations.

\section{WHO ARE THE RETURNEES?}

Before addressing the main research questions and presenting the results, we look at the demographic and socioeconomic characteristics of the returnees and their households and compare these with the non-returnee counterparts. 


\section{Returnee households and other households}

Table 3 compares the characteristics of households who have returnees with households that do not have returnees. The characteristics of returnee and non-returnee households are very similar. For instance, in both cases, about one-fifth of the households are headed by a female, the age of household head is slightly above 40 years, close to 80 percent of the household heads are married and about 13 percent are widows. Returnee and non-returnee households also live in similar communities. These communities are characterized by land scarcity, lack of employment and good ethnic harmony.

\section{Returnees compared to other individuals}

Table 4 compares returnee to non-returnee individuals. The top portion of the table includes all individuals in the sample. Close to half of the returnees are female, they have an average of 36 years of age, $63 \%$ are married, $6 \%$ are widows and they have about 3.9 years of education. In relative terms, returnees are older, more likely to be married or widowed and have more years of education than non-returnees. However, this comparison may not be adequate as the probability of being a returnee increases with the number of years of conflict that the individual experienced. A better comparison will be between adult returnees and adult non-returnees. This comparison is provided in the bottom potion of Table 3 which compares returnee and non-returnee individuals who are 15 years of age or older. Making this change decreases the differences between returnees and non-returnees in terms of age, but it is still the case that returnees are significantly older than non-returnees. In fact, the characteristic of returnees do not change much.

\section{THE IMPACT OF MIGRATION ON THE RETURNEE'S COMMUNITY}

\section{STATUS}


We present results from probit and ordered probit models. Columns 1, 3, 5, 7 and 9 of Table 5, present the results from the probit estimations. For Questions 1, $2,3,5$ and 6 (see Table 2 for the questions used) the dependent variable for the probit estimations takes the following form: Disagree $=0$, Neutral or Agree $=1$. For Question 4 the dependent variable for the probit estimations takes the following form: decreased $=0$, not changed or improved $=1$.

All estimations use clustered standard errors at the community level. Given the straightforward interpretation of the results from the probit analysis we focus most of the discussion on these estimates. However, given the rank order nature of the responses to the statements of interest we also show results from an ordered probit estimation. Column 2, 4, 6, 8 and 10 of Table 5 report the results from the ordered probit estimation. For Questions 1, 2, 3 and 5 the dependent variable is coded as: Strongly Disagree $=1$, Disagree $=2$, Neutral $=3$, Agree $=4$, Strongly Agree $=5$. For Question 4 the dependent variable is coded as decreased $=1$, not changed $=2$, improved $=3$.

\section{Overall, I feel that migration has improved my social status in Burundi}

Columns 1 and 2 of Table 5 show the result for the impact of migration on improvements in community social status. The first column shows the marginal effects for the standard probit estimation. The marginal effect of being female is -0.24 . Even after controlling for other factors there is evidence that female returnees tend feel more negative than male returnees about the overall impact of migration on community status improvements. This result is consistent across the two estimations. Results also suggest that migration length has a significant and positive impact. In this case the marginal effect is small (0.001), but it is important to keep in mind that time spent abroad is measured in months, hence we would expect the marginal impact to be small. 
Other results suggest that having felt part of the host society while living there has a positive effect on the perceived impact of migration on community standing in Burundi. This result may come as a surprise given that this variable reflects affinity to the host society, but it may simply reflect a pre-disposition of certain type of individuals to be more positive about community relationships in general (i.e. whether in the host or home country). Education has a positive effect on the impact of migration on community status falling in line with general expectations. Finally, being in employment has a negative effect in the probit estimation.

This last result is somewhat unexpected. We explored this result further by separating those who are employees (i.e. those in paid work) from those who work on their own business (both are included in the "1" category in the original "dummy" variable) and the analysis suggests that the result is driven by those in paid work. It is likely that many of those in paid work have relatively low quality jobs and this may accentuate the perception of having a lower social status.

[Table 5]

Overall, I feel that migration has increased my ability to contribute to my community

Columns 3 and 4 of Table 5 report the results from the estimations in which the independent variable reports the perceived impact of migration on the returnee's ability to contribute to the community. The results suggest that females are less inclined to agree with the fact that migration has increased their ability to make contributions, while duration of migration seems to play no role in this regard. The results are consistent across estimations. The marginal effect of being female is similar to the one for the previous question about community status at -0.23 . Once again we see that education seems to play a positive role and that some of the community variables such as land availability (negative) and community employment (positive) have a significant impact. The variable which indicates that the household owns 
animals, one of the variables which we include to control for household wealth, has a positive and significant impact across both estimations.

Overall, I feel that migration has alienated me from the community

Columns 5 and 6 of Table 5 show the results for the estimation in which the impact of migration on community alienation is the dependent variable. Results suggest that once we control for other relevant characteristics, there are no major differences across genders in the response to the question. Length of time abroad has a positive impact on feelings of alienation from the community.

Results for the control variables reveal some interesting dynamics. Feeling part of the host society has a negative impact on feelings of alienation from the community. As explained above, it could be the case that some individuals are just better at integrating in the community (or at least they perceive themselves to be better at integrating).

On the other hand, subjective wealth and owning animals have a positive impact on the effect of migration on community alienation. Both of these variables reflect the economic condition of the household. Those with greater means could feel alienated from the rest of the community and this feeling may be accentuated by migration.

\section{THE IMPACT OF MIGRATION ON THE RETURNEE'S HOUSEHOLD}

\section{STATUS}

Compared to prior to your migration would you say that your position in your household has changed at all?

The discussion now turns to the analysis of the impact of migration on household status in columns 7 and 8 of Table 5. Gender does not seem to affect the perceived impact of migration on household standing. However, migration length has a negative and significant impact. The only other variable which is significant is the level of ethnic harmony in the community which has a negative effect. Overall, the independent variables are not able to 
explain much of the variation in perceptions regarding the impact of migration on household status.

It is interesting that the ethnic harmony indicator is significant for the first time in a estimation in which the dependent variables reflects the impact of migration on household level standing, while it was mostly insignificant for the impact of migration on community level status. The results suggest that in communities with greater ethnic harmony, individuals more often perceive migration as having a negative impact on their household standing. The marginal effect of ethnic harmony is about -0.07 .

Overall, I feel that migration has given me more decision making power within my

\section{household}

The last set of results that we present concern the impact of migration on decision making power within the household. Columns 9 and 10 of Table 5 presents these results. The effect of gender on the impact that migration has on decision making power in the household is negative and significant. The marginal effect for gender is -0.21 and the results are consistent across the different specifications.

\section{CONCLUSION AND POLICY IMPLICATIONS}

This paper explores returnees' perceptions of the overall impact of forced migration (including displacement and return) on community and household level status using data from Burundian returnees. The paper places special emphasis on the role played by gender and length of migration in shaping those perceptions.

In general, results suggest that gender does not affect the perceived impact of migration on alienation from the community or the position of the returnee in the household. On the other hand, women tend to be less inclined to think that migration has improved their social status in Burundi, increase their ability to contribute to the community, or to have 
given them more decision making power within the household. Overall, women have a significantly more negative perception of the impact of the migration process on their community and household level status.

It has been over 20 years since the United Nations High Commission for Refugees issued its first policy document dealing with refugee women (UNHCR, 1990). Since then many other guidelines have been issued dealing with topics related to refugee women, including access to reproductive health services and additional protections against sexual abuse (Buscher, 2010). However, our results suggests that an important impact of displacement on women may come from the whole impact of forced migration on societal structure and the possibility of them losing social capital at the community level and decision making power at the household level. These effects have not received particular attention in the policy discourse.

Results also suggest that those returnees who spent longer periods of time abroad have a greater propensity to perceive the migration process as having a positive impact on their social status in Burundi. There has been plenty of discussion in policy and academic circles about the dangers of protracted displacement situations and the detrimental consequences that these situations have for refugees and hosts. Burundian refugees in Tanzania are one of the groups that are often used as examples in policy reports (e.g. UNHCR, 2008). However, our results suggest that in some instances, a longer period in exile before returning may not be bad for all socio-economic aspects and could lead to a better (perceived) societal position later on. The dynamics behind this process would need to be studied further in different situations of displacement in order to reach any definite conclusions.

One final interesting result from the analysis is that those returnees who felt part of the destination country society were more positive about the implications of their migration 
process, including the return process. This included the perception of having an improved social status and less feelings of alienation from the community. This has important implications for policies related to the integration of refugees in host countries and suggests that policies directed at encouraging integration into the host society may be beneficial even in the event of return. 


\section{REFERENCES}

AI, A., PETERSON, C. and UBELHOR, D. (2002) 'War-Related Trauma and Symptoms of Posttraumatic Stress Disorder Among Adult Kosovar Refugees'. Journal of Traumatic Stress 15 (2): 157-160.

ALIX-GARCIA, J. and SAAH, D. (2009) 'The Effect of Refugee Inflows on Host Communities: Evidence from Tanzania'. The World Bank Economic Review 24 (1): 148-170.

ALIX-GARCIA，J., BARTLETT, A. and SAAH, D. (2012) 'Displaced Populations, Humanitarian Assistance and Hosts: A Framework for Analyzing Impacts on Semi-urban Households'. World Development 40 (2): 373-386.

AMNESTY INTERNATIONAL, (2005) 'Burundi: Refugee Rights at Risk : Human Rights Abuses in Returns to and from Burundi' Available at: http://www.amnesty.org/fr/library/asset/AFR16/006/2005/en/4065272f-d4db-11dd-8a23d58a49c0d652/afr160062005fr.pdf accessed 18 August, 2014

ANDERSEN, S., ERTAC, S., GNEEZY, U., LIST, J.A. and MAXIMIANO, S. (2013) 'Gender, Competitiveness and Socialization at a Young Age: Evidence from a Matrilineal and a Patriarchal Society'. Review of Economics and Statistics, forthcoming.

BAEZ, J. (2011) 'Civil Wars Beyond their Borders: The Human Capital and Health Consequences of Hosting Refugees'. Journal of Development Economics 96 (2): 391-408. 
BELLOWS, J. and MIGUEL, E. (2006) 'War and Institutions: New Evidence from Sierra Leone'. American Economic Review Papers and Proceedings 96 (2): 394-399.

BELLOWS, J. and MIGUEL, E. (2009) 'War and Local Collective Action in Sierra Leone'. Journal of Public Economics, 93 (11-12): 1144-57.

BERMÚDEZ TORRES, A. (2002) 'Gender and Forced Migration. Expert guide. Forced Migration Online'. Available at: http://www.forcedmigration.org/research-resources/expertguides/gender-and-forced-migration\#sthash.oV1zTDHZ.dpuf accessed September 24, 2013.

BLATTMAN, C. (2009) 'From Violence to Voting: War and Political Participation in Uganda'. American Political Science Review 103 (2), pp. 231-47.

BOYD, M. and GRIECO, E. (2003) 'Women and Migration: Incorporating Gender into International Migration Theory'. Migration Information Source. Washington, D.C.: Migration Policy Institute.

BUSCHER, D. (2010) 'Refugee Women: Twenty Years On'. Refugee Survey Quarterly 29 (2): 4-20.

CARDOZO, B., TALLEY, L., BURTON, A. and CRAWFORD, C. (2004) 'Karenni Refugees Living in Thai-Burmese Border Camps: Traumatic Experiences, Mental Health Outcomes, and Social Functioning'. Social Science \& Medicine Journal 58 (12): 2637-2644. 
CROSON, R. and GNEEZY, U. (2009) 'Gender Differences in Preferences'. Journal of Economic Literature 47 (2): 448-74.

DALEY, P. (2008) Gender and Genocide in Burundi: The Search for Spaces of Peace in the Great Lakes Region. Oxford: James Currey, Bloomington, Indiana: Indiana University Press.

DAVIS, R. (2000) 'Refugee Experiences and Southeast Asian Women's Mental Health'. Western Journal of Nursing Research, 22 (2): 144-162.

DE HAAS, H. and VAN ROOIJ, A. (2010) 'Migration as Emancipation? The Impact of Internal and International Migration on the Position of Women Left Behind in Rural Morocco'. Oxford Development Studies, 38 (1): 43-62.

DUSTMANN, C. and MESTRES, J. (2010) 'Remittances and Temporary Migration'. Journal of Development Economics 92 (1): 62-70.

EL-BUSHRA, J. (2000) “Gender and Forced Migration”, Forced Migration Review, 9:4-7

FRANSEN, S. and SIEGEL, M. (2011) 'The Development of Diaspora Engagement Policies in Burundi and Rwanda'. UNU-MERIT Working Paper 2011-038.

FRANSEN, S. and KUSHMINDER, K. (2012) 'Back to the Land: the Long Term Challenges of Refugee Return and Reintegration in Butundi' New Issues in Refugee Researc, Research Paper No.242, UNHCR 
GURUJARA, S. (2000) “Gender Dimensions of Displacemen”, Forced Migration Review, 9:4-7

GROSSMAN, M. and WOOD, W. (1993) 'Sex Differences in Intensity of Emotional Experience: A Social Role Interpretation'. Journal of Personality and Social Psychology 65 (5): 1010-1022.

HARShMAN, R. A. and PAIVIO, A. (1987) "Paradoxical" Sex Differences in Selfreported Imagery'. Canadian Journal of Psychology 41 (3): 287-302.

HINTON, D., RASMUSSEN, A., NOU, L., POLlACK, M. and GOOD, M. (2009) 'Anger, PTSD, and the Nuclear Family: A Study of Cambodian Refugees'. Social Science \& Medicine 69 (9): 1387-1394.

HOLLINGSHEAD, A.B. (1975) 'Four Factor Index of Social Status'. Working Paper. Department of Sociology. Yale University.

KONDYLIS, F. (2010) 'Conflict Displacement and Labor Market Outcomes in Post-war Bosnia and Herzegovina'. Journal of Development Economics 93 (2): 235-248.

LEMARCHAND, René, (1974) 'Selective Genocide in Burundi', Minority Rights Group, London. 
LEMARCHAND, René, (2008) 'The Burundi Killings of 1972', Online Encyclopedia of Mass Violence, available at: http://www.massviolence.org/Article?id_article=138. Accessed August 18, 2014

MARTIN, S.F. (2003) 'Burundi: out of sight, out of mind?’ Forced Migration Review, 17: 27-28.

MARTIN, S.F. (2004) Refugee Women. Lanham, Maryland: Lexington Books.

MARTIN, S.F. and HIDDLESTON, T. (2006) 'Burundi: A Case of Humanitarian Neglect'. In Van Hear, N. and McDowell, C. (eds.) Catching Fire: Containing Forced Migration in a Volatile World. Lexington Books. Lanham, Maryland, pp. 15-44.

MERKLE, L. and ZIMMERMANN, K.F. (1992) 'Savings, Remittances, and Return Migration'. Economics Letters 38 (1): 77-81.

ROBINSON, G. and RIISKJAER, M. (2010) 'Joint Evaluation: Evaluation of the protracted refugee situation (PRS) for Burundians in Tanzania', UNHCR Document, available at: http://www.unhcr.org/4cdd4bc29.html, accessed August 19, 2014

NGARUKO, F. and NKURUNZIZA, J. (2005) 'Civil War and Its Duration in Burundi'. In Collier, P. and Sambanis, N. (eds.) Understanding Civil War: Africa. Washington, D.C.: World Bank, pp. 35-61. 
NIYONIZIGIYE, D. and LE ROUX, E. (2011) 'A View on the Current Situation Regarding Sexual Violence in Burundi: The Role of the Church and Possible Avenues for Intervention'. Report Commissioned by Tearfund.

PAVLISH, C. (2007) 'Narrative Inquiry into Life Experiences of Refugee Women and Men'. International Nursing Review 54 (1): 28-34.

PFEIFFER, L.M., RICHTER, S.M., FLETCHER, P. and TAYLOR, J.E. (2007) 'Gender in Economic Research on International Migration and Its Impacts: A Critical Review'. In Morrison, A., Schiff, M. and Sjöblom, M. (eds.) The International Migration of Women. Washington, D.C.: World Bank, pp. 2-49.

RITSNER, M., PONIZOVSKY, A., NECHAMKIN, Y. and MODAI, I. (2001) Gender Differences in Psychosocial Risk Factors for Psychological Distress Among Immigrants. Comprehensive Psychiatry 42 (1): 151-160.

ROGGE, J. (1994). Repatriation of Refugees: A not so Simple 'Optimum' Solution. In: Allen, T. \& Morsink, H. When Refugees go Home. Geneva: United Nations Research Institute for Social Development.

SIDERIS, T. (2003) 'War, Gender, and Culture: Mozambican Women Refugees'. Social Science \& Medicine 56 (4): 713-724.

UNITED NATIONS (1996) Report of the Secretary-General on the Situation in Burundi. Security Council, S/1996/660. New York: United Nations. 
UNHCR (1990) UNHCR Policy on Refugee Women. Geneva: UNHCR.

UNHCR (2008) Protracted Refugee Situations. The High Commissioner's Dialogue on Protection Challenges. Geneva: UNHCR.

UNHCR (2011) Statistiques Démographiques du Rapatriement. Bujumbura: UNHCR.

UNHCR (2012) Central Africa and the Great Lakes: 2012 Regional Operations Profile Central Africa and the Great Lakes. Geneva: UNHCR.

YABIKU, S., AGADJANIAN, V., and SEVOYAN, A. (2010) 'Husbands' Labour Migration and Wives' Autonomy, Mozambique 2000 - 2006'. Population Studies 64 (3): 293 $-306$. 
Appendix A - Independent variables included in the estimations

Variable Definition

\section{Characteristics of the returnee}

Gender

Age

Marital status

Education

Employed

\section{Household variables}

Subjective wealth

Owns land

Owns animals

\section{Migration related}

Length of migration

Part of host society

Time since return

\section{Community variables}

Land available

Employment available

Ethnic harmony
1 if returnee is female, 0 otherwise.

Years

1 if married, 0 otherwise.

Years

1 if in paid work or self-employed in own business, 0 otherwise.

Answer to question: "Compared to other households in this community, how would you currently describe this household?" Options: $1=$ Among the poorest in the community, $2=$ Below average, $3=$ About average, $4=$ Above average and $5=$ Among the richest in the community.

1 if yes, 0 otherwise

1 if yes, 0 otherwise. Limited to poultry (chicken, turkey), goats, sheep, pigs, cows and oxen.

Length of stay abroad in months.

Answer to question: "While living in the country of migration, did you feel a part of the [destination country] society?" Options: $1=$ Not at all, $2=$ A little bit, $3=$ Very much a part of the community.

Number of years since returning to Burundi.

Answer by community leader to the question: "How would you rate the availability of land in this community?" Options: $1=$ Very low, 2 = Low, 3 = Medium, $4=$ High and 5 = Very high.

Answer by community leader to the question: "How would you rate the availability of employment in this community?" Options: $1=$ Very low, 2 = Low, $3=$ Medium, $4=$ High, $5=$ Very high.

Answer by community leader to the question: "How would you say the relationships are between people from different (ethnic) groups in this community? Do people live in harmony here?" Options: $1=$ Very bad, $2=$ Bad, $3=$ Neutral, $4=$ Good and $5=$ Very good. 
Table 1 - Perception of original migration

Overall, I feel that migration has been a mistake
Female
Mean $=-1.32(-10.51 * * *)$
Mean $=-1.62(-22.9 * * *)$


Table $2-$ Responses explored in regression analysis

\section{(A) The impact of migration on the feelings of belonging to the community and overall status in the community}

Question 1: Overall, I feel that migration has improved my social status in Burundi

$$
\text { Mean }=-1.59\left(-2.35^{* *}\right) \quad \text { Mean }=-.85\left(1.85^{*}\right)
$$

Question 2: Overall, I feel that migration has increased my ability to contribute to my community

$$
\text { Mean }=-1.27\left(-2.82^{* * *}\right) \quad \text { Mean }=-.38(2.64 * * *) \quad-.89(-5.40 * * *)
$$

Question 3: Overall, I feel that migration has alienated me from the community

$$
\text { Mean }=.58(3.64 * * *) \quad \text { Mean }=.57(4.57 * * *)
$$

\section{(B) The impact of migration in the returnee's household status}

Question 4: Compared to prior to your migration would you say that your position in your household has changed at all?

$$
\text { Mean }=-.12\left(-2.35^{* *}\right) \quad \text { Mean }=.09\left(1.85^{*}\right) \quad .012\left(-2.98^{* * *}\right)
$$

Question 5: Overall, Ifeel that migration has given me more decision making power within my household

$$
\text { Mean }=-1.47(-14.68 * * *) \quad \text { Mean }=-.88(-8.51 * * *) \quad-.58(-4.04 * * *)
$$

Note: Possible responses for questions 1, 2, 3 and 5: $-2=$ Strongly Disagree, $-1=$ Disagree, $0=$ Neutral, $1=$ Agree, 2 = Strongly Agree. Possible responses Question 4: $-1=$ decreased, $0=$ not changed, $1=$ improved. The value in parenthesis is the $t$ statistic from a t-test. In the case of the means the test evaluates the difference of the mean response from zero (i.e. mid-value). In the case of the difference the test evaluates if the difference between means is significantly different from zero. *** indicates significantly different from zero at the $1 \%$ level, ** indicates significantly different from zero at the $5 \%$ level, * indicates significantly different from zero at the $10 \%$ level. 
$\frac{\text { Table } 3 \text {-Comparison of returnee and non-returnee households. }}{\text { Type of household }}$

\begin{tabular}{lcc} 
& Returnee & Non-returnee \\
\hline & Characteristics of the household head \\
Gender & 0.19 & 0.18 \\
Age & 44.22 & 42.57 \\
Married & 0.77 & 0.79 \\
Widow & 0.12 & 0.13 \\
Education & 3.41 & 3.23 \\
& Characteristics of the household \\
Size & 5.35 & 5.32 \\
Owns land & 0.73 & 0.79 \\
Owns livestock & 0.43 & 0.38 \\
Subjective wealth & 0.52 & 0.58 \\
& Characteristics of the community \\
Land available & 2.12 & 2.00 \\
Employment available & 1.49 & 1.38 \\
Ethnic harmony & 4.15 & 4.16 \\
\hline
\end{tabular}


Table 4 -Comparison of returnee and non-returnee individuals

\begin{tabular}{lcc}
\hline & Returnee & Non-returnee \\
\hline Gender & 0.48 & All \\
Age & 36.03 & 0.52 \\
Married & 0.63 & 19.53 \\
Widow & 0.06 & 0.28 \\
Education & 3.87 & 0.03 \\
& \multicolumn{2}{c}{ Above $\mathbf{1 5}$ only } \\
Gender & 0.47 & 0.53 \\
Age & 36.76 & 31.80 \\
Married & 0.64 & 0.54 \\
Widow & 0.06 & 0.05 \\
Education & 3.89 & 4.01 \\
\hline
\end{tabular}


Table 5 - Regression analysis: Effect on the impact of migration on community and household level social status

\begin{tabular}{|c|c|c|c|c|c|c|c|c|c|c|}
\hline & \multicolumn{10}{|c|}{ Dependent variable is response to question } \\
\hline & \multirow{2}{*}{\multicolumn{2}{|c|}{$\begin{array}{l}\text { Question } 1 \\
\text { Social status }\end{array}$}} & \multirow{2}{*}{\multicolumn{2}{|c|}{$\begin{array}{l}\text { Question } 2 \\
\text { Ability to contribute }\end{array}$}} & \multirow{2}{*}{\multicolumn{2}{|c|}{$\begin{array}{c}\text { Question } 3 \\
\text { Alienation from } \\
\text { community }\end{array}$}} & \multirow{2}{*}{\multicolumn{2}{|c|}{$\begin{array}{l}\text { Question } 4 \\
\text { Position in } \\
\text { household }\end{array}$}} & \multirow{2}{*}{\multicolumn{2}{|c|}{$\begin{array}{c}\text { Question } 5 \\
\text { Decision making } \\
\text { power }\end{array}$}} \\
\hline & & & & & & & & & & \\
\hline & (1) & (2) & (3) & (4) & $(5)$ & (6) & $(7)$ & $(8)$ & (9) & $(10)$ \\
\hline \multicolumn{11}{|c|}{ Characteristics of the returnee } \\
\hline Gender & $-0.24 * * *$ & $-0.84 * * *$ & $-0.23 * * *$ & $-0.76^{* * *}$ & 0.01 & -0.08 & -0.03 & -0.34 & $-0.21 * * *$ & $-0.70 * * *$ \\
\hline Age & 0.00 & 0.00 & 0.00 & 0.00 & 0.00 & 0.00 & -0.00 & -0.01 & -0.00 & -0.01 \\
\hline Marital status & -0.06 & -0.09 & -0.01 & -0.17 & -0.06 & -0.07 & 0.04 & 0.22 & -0.08 & -0.03 \\
\hline Education & $0.03^{* * *}$ & $0.10 * * *$ & $0.02 * *$ & $0.06^{* *}$ & $-0.02 *$ & -0.04 & -0.01 & 0.03 & 0.01 & $0.06^{* *}$ \\
\hline Employment status & $-0.13 * * *$ & -0.32 & 0.13 & 0.36 & 0.13 & 0.17 & 0.07 & 0.30 & $-0.13^{*}$ & -0.37 \\
\hline \multicolumn{11}{|l|}{ Migration related } \\
\hline Length of migration & $0.00 * * *$ & $0.00 * *$ & 0.00 & 0.00 & $0.00 * *$ & $0.00 * * *$ & $-0.00 * *$ & 0.00 & 0.00 & 0.00 \\
\hline Part of host society & $0.11 * * *$ & $0.20 *$ & 0.04 & 0.05 & $-0.20 * * *$ & $-0.51 * * *$ & 0.05 & -0.04 & 0.06 & 0.02 \\
\hline Time since return & 0.00 & 0.01 & -0.00 & 0.00 & -0.00 & -0.01 & 0.00 & 0.01 & -0.00 & 0.00 \\
\hline \multicolumn{11}{|l|}{ Household variables } \\
\hline Subjective wealth & 0.06 & $0.28 *$ & 0.02 & 0.08 & $0.16^{* *}$ & $0.35^{*}$ & 0.07 & 0.23 & -0.03 & -0.14 \\
\hline Owns land & -0.03 & 0.01 & 0.01 & -0.05 & 0.04 & 0.14 & -0.06 & -0.12 & 0.07 & 0.20 \\
\hline Owns animals & -0.01 & -0.17 & $0.14 * *$ & $0.34 * * *$ & $0.15^{* *}$ & $0.32 * *$ & -0.01 & 0.07 & -0.03 & -0.04 \\
\hline \multicolumn{11}{|l|}{ Community variables } \\
\hline Land available & -0.06 & $-0.19 *$ & $-0.10 * *$ & $-0.15^{*}$ & -0.03 & -0.06 & -0.00 & -0.11 & -0.03 & -0.01 \\
\hline Employment available & 0.05 & 0.18 & $0.12 * *$ & $0.29 * * *$ & -0.02 & $-0.19 * *$ & 0.01 & -0.10 & $0.08 * *$ & 0.13 \\
\hline Ethnic harmony & 0.04 & 0.05 & -0.02 & 0.03 & -0.01 & -0.08 & $-0.07 * *$ & $-0.19 * *$ & -0.03 & -0.01 \\
\hline Observations & 240 & 240 & 242 & 242 & 246 & 246 & 225 & 225 & 243 & 243 \\
\hline LR/Wald $\chi^{2}$ & 65.94 & 120.29 & 67.43 & 127.18 & 46.62 & 67.66 & 28.38 & 29.48 & 39.33 & 65.41 \\
\hline Pseudo $\mathrm{R}^{2}$ & 0.24 & 0.12 & 0.14 & 0.10 & 0.14 & 0.08 & 0.11 & 0.08 & 0.09 & 0.06 \\
\hline
\end{tabular}


Figure 1 - Returnees from Tanzania: total and share of total returnees to Burundi

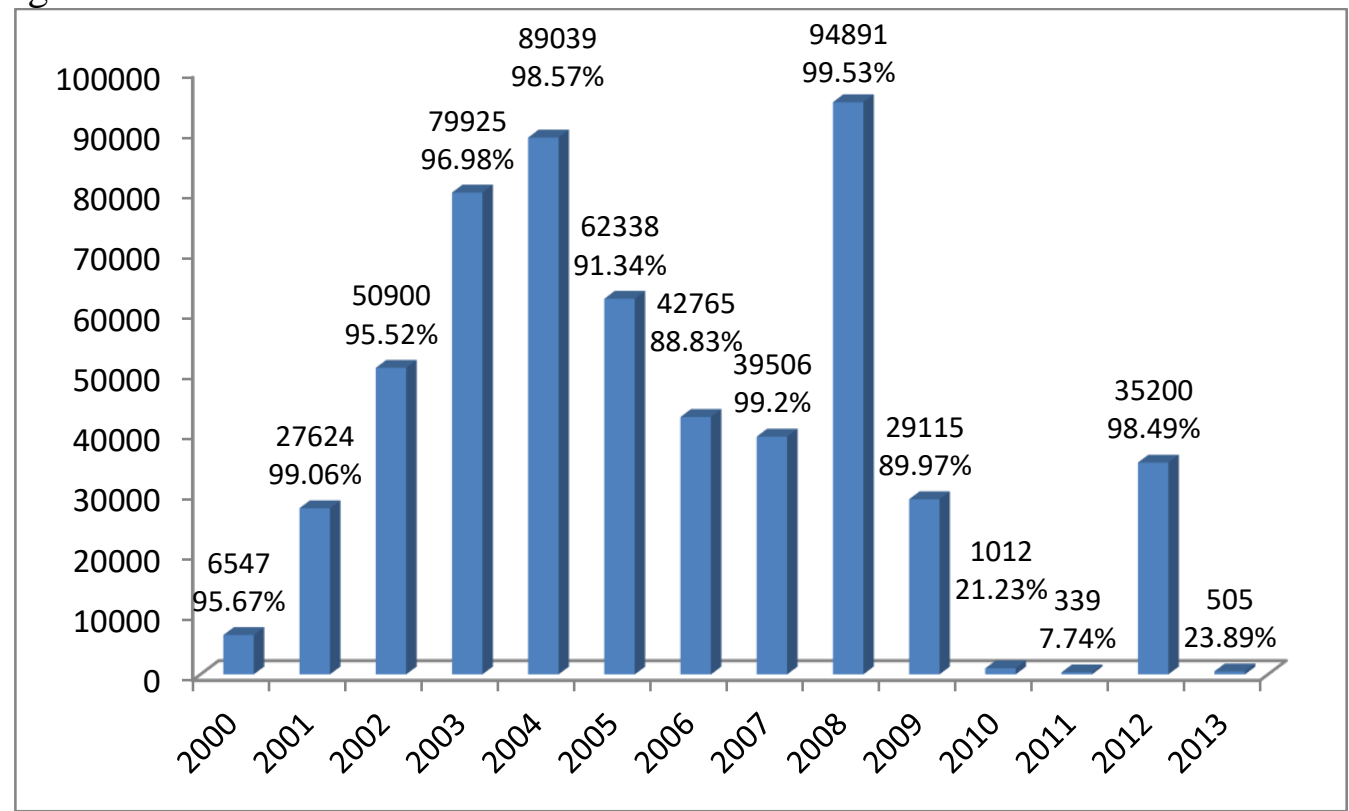

Data Source: Constructed by the authors with data obtained from the UNHCR 